\title{
Exemplary of Limang: The Life Story of Rakoetta Sembiring Brahmana as "Bupati Pejuang" 1914-1964
}

\section{SUPRAYITNO}

IImu Sejarah, Universitas Sumatera Utara

Email: suprayitno@usu.ac.id

\begin{abstract}
Rakoetta S. Brahmana is a name that is still unfamiliar to some of the ears of North Sumatra people, especially for Indonesians in general. Rakoetta, as her comrade and family called her, was a Karo son who was born in the village of Limang, Tanah Karo on August 4, 1914. Rakoetta means glue in the Karo language. By giving that name, his parents hoped that Rakoetta would truly become the glue (unity) for the family and the wider community. This article is intended to re-record the struggle and dedication of Rakoetta as an exemplary figure for what is now known a "fighting" in the Indonesian politics, the Simultaneous Local Election. Rakoetta understood his sociological conditions and Karo culture well because of the influence of his parents. His knowledge of Karo culture became a strong capital in pursuing his political career during the independence struggle in North Sumatra, in addition to his formal education experience at HIS Kabanjahe and Medan Taman Siswa School between 1924 and 1930s. When in Medan, Rakoetta began to come into contact with ideas of nationalism. In Medan political organizations such as Budi Utomo, Sarekat Islam, the Indonesian Communist Party and the Indonesian National Party flourished. During the revolutionary period of independence he was actively involved as a member of Partindo, PNI, Boempa, BPI, BKR until he became regent of the revolutionary period. Rakoetta continued to serve as a Regent of Karo for two periods from 1946 to 1954, and again a Regent of Asahan concurrently Mayor of Tanjung Balai 19541960 and Mayor of Siantar 1960-1964. Rakoetta passed away in 1964. The story of Rakoetta's life saves a bitter and full of ethos of struggle; consistent, resilient, tough, creative, clean and anti-corruption. There are many moral examples that should be emulated from a Rakoetta. The story of his struggle has never been written by anyone.
\end{abstract}

\footnotetext{
Abstrak

Nama Rakoetta S. Brahmana masih terdengar asing di telinga Sebagian besar orang Indonesia. Nama ini biasa dikenal sebagai Rakoetta, adalah milik seorang keturunan Karo, Sumatra Utara. Ia lahir 4 Agustus 1914 di Limang. Ayahnya memberi nama "Rakoetta", yang berarti perekat atau pemersatu. Artikel ini mengulas kehidupan Rakoetta sebagai contoh figure politik dari masa kolonial hingga era awal Indonesia
}

Keywords: independence fighter; local nationalism; North Sumatra; political activism; Rakoetta S. Brahmana

Kata kunci: aktivisme politik; nasionalisme lokal; pejuang 
merdeka. Rakoetta menempuh Pendidikan Hollands Inlandse School (HIS) dan Taman Siswa di Kabanjahe dan Medan antara 1924 - 1930. Ia aktif sebagai anggota Partai Indonesia (Partindo), Partai Nasional Indonesia (PNI), dan beragam organisasi nasionalis lainnya. Rakoetta menjadi bupati Karo selama dua periode, kemudian juga bupati Asahan dan sekaligus merangkap sebagai pelaksana tugas walikota Tanjung Balai 1954 - 1960, dan walikota Siantar 1960 - 1964. Kehidupan Rakoetta penuh dengan perjuangan dan ia tetap mendedikasikan hidupnya bagi kepentingan rakyatnya. Kisah Rakoetta S. Brahmana terlewatkan dalam historiografi nasional maupun lokal Sumatra Utara. Tulisan ini diharapkan mengisi kekosongan historiografi tersebut.

\section{Introduction}

The name of Rakoetta Sembiring Brahmana commonly called by Rakoetta is still very foreign to the ears of North Sumatra people, especially for Indonesian people in general. Rakoetta, as his compatriot and his family called him, was a Karo son who was born in a village called Limang, Tiga Binanga Subdistrict, Karo Regency on August 4, 1914. Rakoetta meant glue in Karo. By giving the name, his parents hoped that Rakoetta would truly become an adhesive (unity) for the family and the wider community. As Customary Elders, their parents often bring Rakoetta in traditional events such as marriage, misfortune, entering new homes, and ancestral ritual ceremonies. From this, his understanding of the sociological and cultural conditions of Karo he understood well. Later it became a strong capital in pursuing his political career in the time of the struggle and independence revolution in North Sumatra, in addition to his formal educational experience at HIS (Holland Inlandsch School) and the Taman Siswa School which he took in Kabanjahe and Medan between 1924 and 1930.

The story of his life saves a bitter memory and a full ethos of struggle; consistent, resilient, resilient, creative, disciplined and anti-corruption. As regent in the revolutionary era, Rakoetta saved many important documents carried by horses tracing the forests in Tanah Karo to Tanah Alas (Aceh). Rakoetta is an example of a regent who is very concerned about education, health, agriculture and the ideology of Pancasila by establishing junior high schools, hospitals, Pancasila education parks and building an agricultural pilot village in Tanah Karo. Rakoetta was the Regent who had been in power for 18 years in different areas, but until finally his life only left a simple house with a tin roof and clapboard for his wife and children. Eating with 'ngebon' in a restaurant in Tebing Tinggi, is his daily story when going to a meeting with the governor's office in Medan. There are many stories of moral exemplary and leadership that are worth imitating from a Rakoetta. This paper is intended to re-record his struggle and dedication so that he can be exemplified by the younger generation and state officials, especially to the regents or mayors in Indonesia. kemerdekaan; Rakoetta S. Brahmana; Sumatra Utara 


\section{Education of Rakoetta}

Rakoetta was born in Limang Village, Tiga Binanga, Tanah Karo on August 4, 1914. His father named Malem Sembiring Brahmin and his mother the Old Shadow br Sebayang. The couple were blessed with three children, namely Rakoetta as the eldest son, Ngaloken Sembiring Brahmin as the second son, and a daughter, but his name and traces were unknown because he died as a child. The name Rakoetta given by his parents was taken from the Karo Language which means a binding. This name was given in the hope that later Rakoetta could become a binding or unifying family and community.

Entering the age of ten, Rakoetta was sent by his father to Kabanjahe to study at his HIS school. When Rakoetta was still in his school, his biological mother, Bayang Tua, Sebayang died. This event gave a deep wound to Rakoetta. Losing one of the people he loves the most makes it a little fragile. But as the eldest boy, Rakoetta did not dissolve in sadness. Thanks to the guidance of his parents, Rakoetta was finally able to wipe out the grief of the incident. Rakoetta finally was able to finish his HIS education in Kabanjahe.

In 1927, after graduating from HIS, Rakoetta continued his education in Medan to enter Taman Siswa School. While in Medan, he lived in Sei Mati, Kampung Baru with Hj Harun Harahap known as Pak Haji. This Hajj does not have children, so they then appoint Rakoetta to be their adopted child. Pak Haji has established him to be a resilient, independent and simple person. Every morning before going to school, Rakoetta is required to wash family clothes on the banks of the Deli river. After finishing washing clothes, Rakoetta walked to the Taman Siswa School.

If school breaks, Rakoetta often returns to her hometown in Limang Village. To get to his hometown, Rakoetta had to take transportation from Medan, which at that time was very difficult to find. The only public transport linking Medan-Berastagi is PMG (Mountain Motor Association). With this transportation, Rakoetta can get to Perbesi Village and from this village, then the journey continues again to Limang Village on foot. The journey from Perbesi Village to Limang Village can be reached on foot for 3 hours. This trip had to be done because there was no transportation to Limang village.

\section{Rakoetta and Political Movements in Tanah Karo}

In Medan City Rakoetta began to come into contact with ideas of nationalism. Because Taman Siswa School is a school that sows the seeds of national awareness by educating students to become national fighters. The Taman Siswa School teachers are mostly political movement activists. In Medan thriving political organizations such as Budi Utomo, Sarekat Islam, the Indonesian Communist Party and the Indonesian National Party. Rakoetta also joined PNI. After graduation, Rakoetta returned to her village, propagate the ideas of nationalism and Indonesian independence. Almost every day he 
made a speech from one village to another to foster the spirit of Indonesian unity and galvanize the community to fight for the ideals of national independence. Because of his activities, he became the target of the Dutch secret police (PID). To get rid of the trace, Rakoetta and her friends are always mobile. He moved from Tiga Binanga, Tiga Nderket and Cane City. In each of these cities, usually in coffee shops people gather to listen to their speeches about the struggle for independence. Sometimes he disguised himself as a seller of household appliances (knives and machetes) in the Three Binanga and Tiga Nderket weeks.

When in 1930 the Dutch Colonial Government carried out repressive actions against the movement by dissolving the activities of political parties and closely monitoring their activities, Rakoetta remained firm to take part in the political world. Rakoetta became a member of the Indonesian Party (Partindo) because the Indonesian National Party was dissolved on April 25,1931 . The dissolution of the Indonesian National Party was inseparable from the capture of PNI leaders in various regions. The day after the PNI dissolution, several PNI figures such as Mr Sartono, Sukemi and Munadi later formed the Indonesian Party (Partindo) on 29 April 1931. Partindo was the new face of the PNI and nationalists. Rakoetta joined Partindo until Japan entered Indonesia in 1942.

Japanese military government dissolved all political organizations. But the movement does not lose its mind. Rakoetta realized that a struggle for independence requires an organization to equate perception in the strategy of struggle. Together with Selamat Ginting, Keterangen Sebayang, Nerus Ginting, and Nolong Ginting they agreed to form the Karo branch of the Indonesian Committee. Through the Indonesia Karo branch committee they made a resolution to be read before Japanese authorities in Kabanjahe. To read the resolution, then go to Kabanjahe Rakoetta, Selamat Ginting, Keterangen Sebayang, Nolong Ginting and Nerus Ginting. As the spokesperson for this resolution appointed Rumpia Bukit. After entering the office of the Japanese superior, Rakoetta read out the resolution that had been prepared. The essence of the resolution was that the Indonesian people thanked Japan for freeing Indonesia from the grip of Dutch colonialism and hoped that Indonesia's independence would be accelerated to jointly foster Greater East Asia. The resolution of the Indonesian Committee read by Rakoetta is refresentation of the public's voice about its desire to free themselves from the shackles of colonialism.

It didn't stop there, Rakoetta, Selamat Gintig and several other movement figures also formed a cooperative called Pusera (People's Economy Center). This cooperative was formed with the aim of fostering Karo community awareness about the importance of building independence both economically and politically. This Pusera organization is in great demand by 
Karo people, especially former PNI and Gerindo members. Not surprisingly, in a short time, Pusera already had 8,000 members with 5 rupiahs of Japanese money each. Rakoetta and Selamat Ginting are believed to be in control of Pusera's organization, assisted by Basar Sianipar and Mantas Tarigan as Secretary and trade sector. Rakoetta and her friends hope that this organization will be able to reach all Karo Land as a tool for new political struggle, because Japan officially dissolves all political organizations.

There was an intersection of interests between the struggle for independence and Japanese efforts to mobilize the people to support the war against the Allies. So to mobilize all the potential that exists in the community to be able to help Japan, the Asia Oentoek Membatoe Defense Agency (BOEMPA) was formed. BOEMPA whose headquarters are in Medan then opened new branches in various regions including in Tanah Karo. BOEMPA in Tanah Karo is led by Raja Oekum Sembiring, a famous autobus businessman in Tanah Karo by bus branded Cap Nenas and Rakoetta as his representative (Eva Engelina Sembiring, 2006: 36). BOEMPA Karo branch then opened twigs and twigs to the villages in Tanah Karo. With the BOEMPA activity, finally many Karo youths entered Heiho (voluntary armies) and Gyu Gun (homeland defenders). They were sent to Medan to be tested at the Medan Helvetia Military Camp. Those who escaped were sent to Siborong-borong for six months of military training, including Djamin Gintings (Suprayitno, 2016: 33-34).

There are several BOEMPA figures in Tanah Karo such as Matang Sitepu, Rakoetta, Kendal Keliat, Raja Oekum Sembiring, Nerus Ginting Suka, Djema Bangun and others. Raja Oekum Sembiring asked Rakoetta that this BOEMPA organization could develop in the community. Through deliberation it was decided to use BOEMPA as a means of continuing the Indonesian national movement. At that time Japan promised to help Indonesia to gain independence. Therefore BOEMPA was very keen to propagate the ideas of Indonesian independence to villages in Tanah Karo, in preparation for welcoming the promise of independence from Japanese rulers. Rakoetta was assigned by the PUSERA (People's Economic Center) leadership board to accompany King Oekum Sembiring and other BOEMPA members to visit the entire Urung Kingdom in Tanah Karo to build nationalism among the Urung kings.

After the Japanese surrendered to the Allied Forces, Soekarno-Hatta proclaimed Indonesian independence in Jakarta on August 17, 1945. This news of the proclamation of independence then spread to all parts of Indonesia, including to North Sumatra. Officially, the proclamation of independence in Medan was announced at Merdeka Square, on October 6, 1945, about two months late. Even though Indonesia was independent, the Dutch still tried to take control again. On October 10,1945, exactly 4 days after the reading of the 
text of the proclamation by the Governor of Sumatra Mr. T.M. Hasan faced thousands of people at the Medan Esplanade (Merdeka) Square, 800 troops from the Royal Altelery 26th Indian Division under the leadership of Brigadier General TED Kelly landed at Belawan Harbor. Members of this allied force were immediately deployed to a number of places in East Sumatra, including Berastagi, Tanah Karo. In the group the allied forces participated in the Dutch military forces with the aim of re-colonizing Indonesia, while allied forces were assigned to guard the Staatus Quo and disarm the Japanese forces.

This situation certainly makes the political atmosphere hot. At the same time, TKR was immediately formed to replace the role of BKR, in Medan under the leadership of Achmad Tahir. In Kabanjahe, on 29 September 1945 a Barisan Pemuda Indonesia (BPI) was formed to respond to BPI's instructions in East Sumatra, with the task of spreading the news of the proclamation and mobilizing the people to support the R.I proclamation, such as forming a BPI branch in the villages. BPI Tanah Karo was led by Matang Sitepu as general chairman and assisted by Payung Bangun, Tama Ginting, Selamat Ginting, Ulung Sitepu, Rakoeta Sembiring Brahmana, R.M. Pandia, KaroKaro Newspaper and others.

BPI's duties included collecting weapons by seizing from Japanese forces, as happened at Tiga Arrow on December 9, 1945. In the BPI, a military force was formed under the name Djamin Army under Djamin Gintings, former Lieutenant Gyugun together with Selamat Ginting, Bom Ginting, Nahud Bangun, Rimrim Ginting, Tapak Sebayang and others. BPI then changes to BKR and then TKR. Members of Tanah Karo TKR are mostly former members of Gyugun or Heiho. Military conflict between Dutch Allied / Nica forces and TKR finally took place in Tanah Karo. Armed clashes and other events that accompanied the course of the independence revolution have affected the process of establishing a government system in Tanah Karo (Suprayitno, 2017: 9-10).

As we know that after the PPKI session in Jakarta, each region is obliged to form an Indonesian National Committee in areas including in East Sumatra led by Loeat Siregar (1945.Koleksi SekNeg RI, ANRI.). While the Karo Regional KNI was formed in January 1946 with the following composition of the board; Chairperson (Rakoeta Sembiring Brahmana); Secretary (Mbaba Bangun), Members (Selamat Ginting, Tama Ginting, Koda Bangun, Nitipi Bangun, Tokoh Purba, L.Siahaan, Mbab Bangun, Sutan Soaloan, Nolong Ginting Like, Netap Bukit, Rachman Sebayang, and Kunci Purba) ( A.R. Surbakti, 1995: 35). The formation of the KNI and TKR in Tanah Karo is a testament to the readiness of the Karo community to form a regional government in Tanah Karo and release everything with the Dutch system of government and mobilize the people to support the proclamation of independence on 17 August 1945. 
As Chair of the Tanah Karo KNI, Rakoetta actively moves to form a Republican government in Tanah Karo that is in accordance with the aspirations of the people. The urge to build a democratic government system continues to stir in the community. In Tanah Karo, Sarwono as the PP Sumatra Chair called Tama Ginting the chairman of the Taanah Karo Struggle Union to carry out arrests of the Sibayak and Raja Urung. In a hurry, Selamat Ginting as his representative on March 3, 1946 invited all sibayak and several Urung kings at meeting of the Struggle Union at the Sultan Deli Bungalow, in Gundaling, Berastagi. In the invitation mentioned there will be leaders from Java to give directions. After all were present, Selamat Ginting opened the meeting saying that the meeting had been cut off and all those present had to enter the Truck which had already been prepared outside the building. A total of 17 people from the meeting were arrested and then held captive in Kutacane. Also arrested was the Deputy Government of the Republic of Meliala and Nerus Ginting Suka and his sister Nolong Ginting Suka. In this incident there was no bloodshed.

Responding to the incident, on March 5, 1946 the Deputy Governor of Sumatra, Dr. Amir and TRI East Sumatra Commander, Achmad Tahir immediately held a meeting. Present at the meeting; Resident of East Sumatra, Tengku Hafaz, Loeat Siregar, Yunus Nasution, Mr. Muthalib Moro, Mahruzar, Mohammad Yusuf, Tengku Dhamrah, Tengku Dr. Mansoer, and the Sumatra Police Chief. Dr. Amir announced the replacement of Tengku Hafaz with Yunus Nasution as Resident of East Sumatra. Siregar Loeat was given the task of being a peacemaker in efforts to restore security and order. Loeat and Yunus were then assigned to travel to various regions in East Sumatra to hold negotiations to prevent acts of violence against the kingdom. In his task, the two figures urged the KNI in the East Sumatra region to immediately remove the royal system.

On Friday, March 8, they came to Kabanjahe to meet with the Head of the Karo Regional KNI chaired by Rakoeta S.Brahmana and PP Tanah Karo. Located at the home of a priest in Kabanjahe, a meeting was held to discuss the abolition of the royal government. During the meeting there was a tension between Yunus and Loeat on the one hand with Selamat Ginting cs on the other hand. Selamat Ginting requested that the representatives of the Republican government immediately decide to separate Tanah Karo from Simalungun. Because all this time Tanah Karo is part of Afdeeling Simalungun en Karolanden. Selamat Ginting wants a broad autonomy for Tanah Karo.

Although the meeting had a score, they finally agreed to form a government separate from Simalungun and formally abolished the royal government in Tanah Karo. Tanah Karo was made a separate government and appointed Rakoetta Sembiring Brahmana as Head of Government. The appointment of Rakoetta was actually agreed upon by Ginting and 
Tama Ginting at a meeting in Kuta Gadung, after the events of 3 March 1946, between 6 or 7 March. Because after the announcement Dr. Amir on March 5, Selamat Ginting received information from Medan, that Loeat and Yunus Nasution were going to Tanah Karo to resolve the excess of the social revolution. (Reid,1987: 380; Tridah Bangun, 1994:93; Biro Sejarah Prima; 290-312; Soeloeh Merdeka, 9 Maret 1946). For that they prepare who will be agreed as the head of government later after Yunus Nasution and Siregar Loeat come to Karo. So the meeting on March 8, 1946 was finally agreed to;

1. Removing the system of self-government / civil society in Tanah Karo.

2. Appointed 18 Luhak Heads to replace King Urung.

3. Establish Rakoeta Sembiring Brahmana as Head of Karo Regional Government.

4. Divide Karo Land into two financial regions, namely Kabanjahe and Tigabinanga Planning (A.R. Surbakti, 1978: 107).

\section{Rakoetta's Service to the Republic of Indonesia}

After the government structure in Tanah Karo was changed, the Indonesian National Committee of the Tanah Karo Region changed its name to the Karo Regional People's Representative Council. In addition to being the Regent of Tanah Karo, Rakoetta also served as chairman of the Regional Representative Council with Selamat Ginting. Rakoetta led the government of Karo Regency for two periods, from 1946-1949 and 1949-1953. This proves that the people and government of the Republic of Indonesia under President Soekarno strongly believed in their performance and ability to lead the government in Tanah Karo during the revolutionary independence. Throughout his career, he became Karo Regent, he was able to carry out his duties running the government of the Republic of Indonesia; accompany Vice President Mohd. Hatta, as long as he visits Tanah Karo and guards Mohd's personal safety. Hatta reached the border of Tanah Karo and Dairi, returning to Bukit Tinggi under the threat of a Dutch fighter. As Regent, in August 1947 Rakoetta ordered health officials to send medical officers to visit villages to help sick and war victims due to Dutch Military Aggression I (Surat Keterangan Kepala Djabatan Kesehatan Kabupaten Karo , 24 Agustus 1947). Rakoetta was also able to prove the existence of a republican government, even though the Kabanjahe city was controlled by the Dutch military in Military Aggression II.

After the Dutch launched Military Aggression II, on 19 December 1948 the republican forces along with the civilian apparatus of the Karo District Government evacuated and guerrilla into the interior of Tanah Karo. During this period a military military government was formed which combined elements of civil and military. The Tanah Karo area was included in the territory of the Aceh Military Governor, Tanah Karo and Langkat 
under the leadership of Daud Beruehueh and Jamin Gintings IV Regiment Commander was made Deputy Military Governor. The establishment of the Military District Government of Karo District was decided on April 2, 1949 in Kuta Cane. Lieutenant Colonel A.E. Kawilarang, as Commander of the VII Command of the Sumatra Command Teritorium, issued a Decree on April 4, 1949 concerning the composition of the Karo Military Command Office as follows; Head of PPMK: Rakoetta S. Brahmana, Deputy I PPMK: Wedana Keras Surbakti, Deputy II PPMK: Wedana Netap Bukit, Head of Secretariat: Office of Tarigan, Treasurer: Tambaten Brahmana, Information: Ridwan Tarigan, Social: L. Siahaan, P \& K: Klewet Purba . At this time Karo District supervised two Kewedanaan namely North Karo Wedana: Kendal Keliat in charge Kec. Pancur Batu Timur: Selamat Tarigan; Kec. Pancur Batu Barat: Dame Guru Singa; Kec. XII Kuta: Nahar Purba; Kec. Batu Karang: Nitipi Bangun; Kec. Kutabuluh: Masa Sinulingga; Kec. Mardinding: Tuah Purba dan Wedana Karo Selatan: Matang Sitepu yang membawahi Kec. Tiga Binanga: Likat Ginting; Kec. Barus Jahe: Bobo Sitepu; Kec. Suka: Jamin Karo Sekali (Tridah Bangun, 1994: 272-273).

The territory of the Karo Military District Government is far into the border area claimed to be controlled by the NST government. This government is effective in propagating to the public to always support the republican government. At the time of the 2 nd military aggression, most of the NST territory was controlled by the people's army and the TNI. All Tanah Karo, since December 19, 1948, is only theoretically under NST government supervision. NST officials such as Hoofd's Onder District were stationed in a number of villages, since the guerrilla war was over. They fled to cities where fortifications of Dutch and Blauw Pijper troops such as Kabanjahe, Berastagi, Tigabinanga, Munthe, Binjai, Deli Tua and Pancur Batu (J.J van de Velde, 1987: 237; Tridah Bangun, 1994: 307). This means that although the city of Kabanjahe and some administrative areas of Karo Regency are controlled by NSTs and Dutch military forces, the Karo District government under the leadership of Rakoetta Regent Sembiring Brahmana still exists. As the Karo Regent, he remained steadfast in running the government in refugee camps, from Tiga Binanga to Kuta Cane. He continued to work to mobilize the people to support the struggle for independence and at the same time prepare logistics, including printing money with registration number 20490 worth Rp.1000. Regency money is typed and signed by Rakoeta S. Brahmana and affixed with a district stamp. This money was printed in Tigabinanga to expedite the economy and the need for TNI troops who would fight Dutch troops throughout the Tanah Karo battle front to Medan Area. While taking refuge in Lau Baleng to Tanah Alas, he always tried to bring in the documents of the Karo Regency government so that it would not be taken by Dutch troops. That way, Rakoetta Sembiring Brahmana still serves as the Regent 
of Karo Regency, even though most of the Karo region, especially big cities, is controlled by NST.

Rakoetta was able to mobilize the PRS to support TNI military operations and carry out instructions from the Commander of the SubTerritorial VII Command of Sumatra, A.E. Kawilarang carried out the task of the Business Administration of the Republic of Indonesia (BUMPRI) during the 1949 guerrilla war. The tasks of the BUMPRI which was formed on 27 April 1949 included regulating and controlling the distribution of goods from the interior of the republic and enemy occupation areas (Tridah Bangun, 2002: 2016-2017). These tasks were able to be carried out properly so as to support the smooth operation of the TNI in launching guerrilla warfare against Dutch forces and finally forcing the Dutch government to recognize the sovereignty of the Republic of Indonesia 27 December 1949.

Rakoetta is a regent who cares about the development of public education. Therefore since the beginning of his reign, in September 1946, Rakoetta S. Brahmana together with L. Siahaan and Mbaba Bangun have been able to build junior high schools in Kabanjahe. The director of the school is held by Baria Sitompul. Because of the many interests in entering this junior high school, a private junior high school was built with the name Nusantara Middle School with the director Mbaba Bangun. As a result of Dutch Military Aggression, in 1947 this junior high school was moved to Tigabinanga and in 1948 it was moved again to Kuta Cane. In 1949 this junior high school was moved again to Batukarang (A.R. Surbakti, 1995: 42). Likewise there are already 94 education courses with 4462 students and 128 teachers. The General Knowledge Course was also opened in March 1951. Intermediate Library has also been opened in Kabanjahe and 4 Low Library was established in 4 Sub-districts. To strengthen the ideology of Pancasila among the people a Park of the Pancasila Library was established in Berastagi. In the health sector, the Lung Hospital in Kabanjahe has been built and in the agricultural field 250 hectares of farmland have been opened in Tigabinanga which was done for 3 weeks. (Mestika Newspaper , Tuesday, 30 October 1951, page 6-7, hlm.3; Waspada, 1951). He also built a pilot village in Tiga Panah District. His monumental work was to build the Heroes' Tomb in Kabanjahe as a tribute to the freedom fighters who had fallen on the battlefield against the Dutch colonizers. The Kabanjahe Heroes' Tomb was inaugurated on August 17, 1951 along with Tugu Abdi Dharma located at the Kabanjahe Post Office Round.

The trust of the people and the Government of the Republic of Indonesia to the Rakahetta S. Brahmana turned out to continue. After spending his service in Tanah Karo, Rakoetta was again trusted by the Government of the Republic of Indonesia to become the Regent of Asahan while simultaneously serving as Mayor of Tanjung Balai from 1954 to 1960. 
During his leadership in Asahan, Rakoetta invited the public to pay attention to the food conditions in the area. To maintain food availability, especially rice, he encouraged people to plant rice. Rakoetta saw that the indigenous people of Asahan had no interest in rice cultivation because they generally lived from fishing, so he brought Karo people from the mountains to open rice fields in Asahan (Eva Angelia Sembiring, 2006: 52-53). Karo people are indeed identical with agricultural activities because they quickly adapt to the agrarian culture in the Asahan area. The Karo community in Asahan still exists as farmers. Rakoetta served as regent in Asahan District for six years, from 1954-1960. As long as he leads in the Asahan Regency he tries to lead wisely and firmly so that he can be accepted in an area that is not his homeland. Appreciation of the Asahan community towards Rakoetta is evidenced by the presence of the name Jalan Rakoetta in Tanjung Balai.

From Asahan, Rakoetta was again trusted to be Mayor of Pematang Siantar from 1960-1964. During his tenure as Mayor Siantar, Rakoetta and his children and wives occupied official homes, the former Simalungun Resident Assistant Office colonial period which is currently located on Simbolon Street, Pematang Siantar City.

A unique story needs to be explained here with regard to its position as Mayor of Pematang Siantar based on his son's story. As a Mayor to live in luxury may not be difficult for Rakoetta. But that is not the character of Rakoetta. Rakoetta, which was forged by a parent by hard work, tenacious and simple, still does not dazzle with the persuasion and seduction of entrepreneurs to act corrupt by accepting bribes or tribute. As an independence fighter who was very well aware of the suffering of the people during the period of political movement and the independence revolution, he remained istiqomah with the principle of building a clean and just government. With this principle, 'a bundle' of money given to him by businessmen working on infrastructure development projects in Pematang Siantar is still returned to their owners. There were also contractors who had been refused by Rakoetta to get the project, came to his house to meet his wife and gave envelopes containing money. When Rakoetta returned home, his wife handed the money to Rakoetta. Rakoetta was immediately angry, "I returned the money, I refused it when I came to the office". Finally, the driver who surnamed Simare-mare was told to deliver the envelope containing the money to the entrepreneur. This was the firm attitude of Rakoetta towards anyone who wanted to bribe him.

Simple life patterns also remain taught to family members. Her children are always given cloths of clothing to sew to the tailor. The size must be large so that it can be worn for a long time, so it can save for several years. One time his children brought the cloth to the tailor asking for clothes that were not wide. Seeing his son's behavior, Rakoetta was angry. With this principle 
of life, Rakoetta was known as a regent who until the end of his life did not have excess assets. The money left for his wife and children is a house located on Mahoni Street, Pasar II, Padang Bulan Medan, roofed with zinc, cement floor, planked walls without electric lighting. This house he bought when he was still the Regent of Asahan. One of his children recalled how difficult it was to be the son of a regent / mayor at that time. "Imagine from an official house, the former Simalungun Resident Assistant office building in Pematang Siantar moved to a boarding house that slept with oil lamps (teplok), so in the morning our noses were black and black with smoke from teplok lights". After Rakoetta's death, his wife Ngamini br Sebayang returned to farming to support her five children.

When he became the Asahan Regent, his children were often taken to Medan, if the Rakoetta was to meet with the Governor's Office. After lunch, always stop at Tugu Restaurant, owned by Pak Haji in Tebing Tinggi. After eating, the children were always told to enter the official car of the Chevrolet brand in 48. One day a child overheard what Rakoetta said to the restaurant owner "come to see Pak Haji, go home from Medan I paid". That is how Rakoetta always does, always eating "ngebon" because of not having money. He paid after getting a salary after returning from the Governor's Office in Medan.

Rakoetta's simplicity can also be known from her eating habits. Rakoetta always carries jengkol in each pocket of his coat. If there is a reception in Medan or other places, he is looking for a place that is right (mojok) to eat with his favorite Jengkol side dish. His love for jengkol has been planted since he was a child. Every day when he walks from his house goes to Tiga Binanga school, a small town about $15 \mathrm{~km}$ from his home in Limang, he always brings lunch and salt. While walking along the road which is on the right and left side of many Jengkol trees, he takes the jengkol for his food later in school. This simple lifestyle is always conveyed to his children especially when eating together at home. "Advice and advice live simple, disciplined, hard work, firm and honest, one word with deeds, quickly sliding from the mouth of the father". Thus his son remembers Rakoetta's character. Rakoetta most does not like pretending. He wants humans to be honest and open. One example when Rakoetta offered to eat "his men". You want to eat satay, they say you want to pack, but there is one person who answers shamefully not sir. Rakoetta then ordered satay and they were welcome to eat. When one person who stated he did not want satay was about to eat, was shouted by Rakoetta "don't you eat the satay, because you were offered not to want". This seems cruel, but actually Rakoetta teaches honesty and openness, one word with deeds. That is the essence of the lesson that Rakoetta wants to convey to its members. Conversely if someone has a very big desire for something, then that person must be instructed to do it until it can. Rakoetta always gives an 
example by asking someone whether the employee or his colleagues. "What do you want, they answer, I want to eat chicken so much," he ordered a lot of chicken and told them to eat it to their heart's content until they had no sense of wanting to eat chicken anymore.

Rakoetta is an example of a leader who was very loyal to Dwi Tunggal Soekarno Hatta. His closeness to the Great Leader of the Revolution was shown by his visit to the Presidential Palace without protocol. When he was received at the State Palace, he was asked by the president, "what is the need for Pak Sembiring to come here. Rakoetta replied, I asked to stop being the Regent. Soekarno was stunned then asked why, Rakoetta replied, because Dwi Tunggal had separated. But that intention was later undone when Sukarno explained that although Hatta was not Vice-President, we still met and communicated to discuss the nation's problems. The decision was taken the next day, after he was told by Bung Karno to reconsider his plan to withdraw from the Bupati. "How Pak Sembiring said Bung Karno, Yes sir today I will go back to Medan to remain a Regent". Thus his son recalled, the story told by Rakoetta to him. Bung Karno's closeness could also be identified through the gift of Bung Karno on every Rakoetta birthday in the form of pictures of Bung Karno's children such as Megawati, Rachmawati and Sukmawati. Many of the gifts from Bung Karno have been lost. Among the most important things to explore further the truth is that Rakoetta is the person most trusted by Bung Karno to be consulted on various problems in North Sumatra, including the appointment of strategic positions in government bureaucracies such as the Regent and Mayor. This information was obtained from his son Netapken Sembiring Brahmana from the PNI North Sumatra figure, Syamsul Hilal.

\section{The idea of Rakoetta on Karo Culture and Grounding Pancasila}

Writing difficulties when trying to recount Rakoetta ideas or thoughts about culture, especially Karo culture. Because of the lack of data about Rakoetta. Many documents are lost or burnt when scorched earth actions and bad diseases of our society are less concerned with archives. The next narrative is only based on one Rakoetta thought in the form of a paper that was resumed by Riah B. Sembiring in a small book entitled Karo Culture Scribble Scatter (Riah B. Sembiring, 1984). Five Rakoetta writings that use the pseudonym Santara had actually been published in Terlong magazine in 1963 and 1964. The four writings were about karo culture (Karo inheritance rights, revealing Tarombo Karo, the task of the Beru as a moral judge, the origin of the minister's children and about Building a Pancasila Community in Karo.

Rakoetta's concern about culture has long been growing, perhaps thanks to her parents' upbringing of a traditional elder in Limang. The love of the Karo culture was manifested in various programs when he became 
a regent both in Karo, Asahan and Pematang Siantar. Just like in Asahan, he established a Karo village in the Lau Cimba area near Rambung Merah complete by building a place where Karo people hold meetings or parties that are called "jambur". There is an interesting thought from Rakoetta about the inheritance rights of Karo people. For Rakoetta, Karo women do not get inheritance rights, but they get keleng ate (love) which is higher than the material rights given to boys. In reality, conflict or dispute comes from the struggle for inheritance rights in the form of material or objects. When services or rights are over, the value starts and the conflict or dispute can only be solved with compassion. Disputes can be resolved perhaps through trial, but the inner dispute of being a chaff that can sometimes become a fire that burns the human soul to fight each other over material. This is the basis for Rakoetta to explain why Karo women do not get inheritance rights.

Rakoetta emphasized the importance of building a sense of compassion, compassion, holiness in society in order to build national identity. Furthermore, he explained that keleng ate is "the pay of tendi (soul) which is patterned on the individual (personal person). The pattern is all unseen things that are not visible. Its nature is not just appreciation, but purity, excellence, authenticity and authenticity. Keleng is free from all stains, apart from hatred and jealousy. Keleng ate knows no hostility, so he can overcome vanity. If opposed, it will cause regret throughout life. Keleng ate is given entirely to the daughter, by her parents, her siblings even by everyone. Keleng ate is the sacredness of life, is the keris saktinya emanating from the character of life and society. Keleng ate, sourced from the heart, vibrates in the flow of blood and flesh, covering all the marrow and mind. He was brought as a sinner to the afterlife".

In his writings Rakoetta deeply regretted the negative attitudes arising from the struggle for material. Because conflicts that arise in the community greatly disrupt the national development process. "I shed tears when I researched and remembered things that were negative. We are all of them, he is a man, he is a woman, it is a tool of our shared society, which will find a national ideal, is in accordance with the ancient customary call that we have never been able to realize during those old customs. This does not mean, that I am just inclined to defend the ancient customs or customs that are in existence, but I am very inclined to our national ideals now ... "With this Rakoetta advised us, that the strength of local culture (ancestors) can be used as capital social in national development to strengthen national identity.

Pancasila according to Rakoetta does not conflict with the customs and culture of Karo. Customary idealism is a natural heritage of thought possessed by the people and perfects its steps towards the Pancasila community. Ideal adat has a teacher to achieve a higher level, namely Pancasila and the 1945 Constitution. The problem is how to fight for the values of Pancasila to be used as a guideline to act in a society that has carried out traditional values 
for generations. The method of propaganda with a spirit-burning tactic is useless because the community has been quite burned with the spirit of the struggle. Now the development period, the strategy must also be adjusted to the conditions of the times. Education is the main key, according to Rakoetta. So from the beginning he served as regent in Tanah Karo, the first program was to build schools and public education parks. As mentioned above, to strengthen the ideology of Pancasila among the people he built a Pancasila Library Park in Berastagi.

Society must be made aware of our noble ideals of establishing an Indonesian state and nation, namely a just and prosperous Pancasila society. Communities without oppression by both individuals over other individuals and by a nation to other nations. Material and fair moral happiness in society is not just and prosperous for individuals. Fair and prosperous society controlled by the government and the state. According to Rakoetta, realizing the Pancasila society is not difficult as long as we are diligent, mutual cooperation, collective, cooperative and kinship. All these noble traits are embedded in the Karo indigenous community. It's a pity the writer can't understand more about his idea to build the Pancasila community, because the three-piece writing edited in the Corat Karet Culture Correspondence book seems to be still in line and the writer doesn't get it.

\section{Conclusion}

Rakoetta Sembiring Brahmin died on January 28, 1964 in Kabanjahe after undergoing intensive treatment at Elisabeth Medan Hospital due to Lever's disease. On the day of his funeral at Kabanjahe Heroes Cemetery, many people grieved, feeling the loss of an honest, strict, disciplined, and simple Regent Regent. The story of his life was colored by sincere devotion to the State of Indonesia, even though in difficult conditions, full of danger and lacking. Rakoetta only left a simple boarded house, zinc roof and cement floor for his wife and children. It was in stark contrast to the political position he held from 1946 to 1964 as a two-period regent in Tanah Karo and the Regent of Asahan and the Mayor of Pematang Siantar.

So when the Jokowi-Jk government heavily campaigned for the Mental Revolution and the number of Regents, Mayors and Governors captured by the KPK for engaging in corrupt practices, Rakoetta's life story really deserves to be exemplified and practiced by state officials. The author hopes that there will be many stories of honest bureaucrats in Indonesia whose biography must be written and used as teaching materials for anti-corruption education for school children to shape the character of anti-corruption from an early age in Indonesia. Of course one of them wrote a biography of Rakoetta Sembiring Braahmana as the Regent of Fighters from Limang Tanah Karo, North Sumatra. 
As a tribute to the struggle and dedication to the nation and state, on November 10, 2012 on the initiative of the Rakoetta Brahmana Center, the Karo District Government finally broke the name of Jalan Rakoetta S. Brahmana as a substitute for the name of the Kutacane Street that connects Karo District with Southeast Aceh. The sacking of the name Rakoetta Street was indeed good enough to introduce Rakoetta's struggle to the wider community, but it would be more appropriate if the Government of the Republic of Indonesia gave the title National Hero to Rakoetta S.Brahmana. Because Rakoetta is a figure who deserves to be an example for all citizens of the nation. The story of his life can inspire many people to serve totally to the state, professionals and be able to maintain the credibility of his government from all kinds of challenges in crucial times of the journey of the Republic of Indonesia government from the time of the independence revolution to the 60 s era.

\section{References}

Bangun, Payung. Dari Medan Area ke Sipirok Area.Stoottroep Brigade "A" Tanah Karo dalam Perang Kemerdekaan (1945-1950). Jakarta: Yayasan Merga Silima, 1988.

Bureau Republik Indonesia Bagian Penerangan Djakarta, Pembagian Daerah Dalam Propinsi Sumatera 1948 Kantor Gubernur Sumatera Bukit Tinggi, Koleksi ANRI, Djokja Documenten No. 260.

Pemerintah Poesat Soematera, Boekoe Satoe Tahoen Pemerintah NRI di Sumatera, Pematang Siantar, 1946.

Reid, Anthony. Perjuangan Rakyat: Revolusi dan Hancurnya Kerajaan di Sumatera, Jakarta: Sinar Harapan, 1987.

Riah B. Sembiring, Corat Coret Budaya Karo, Medan: U.P. Ulamin Kisat, 1984.

Sembiring, Eva Angelia, "Biografi RakoettaSembiring Brahmana”, Skripsi S1, Jurusan Sejarah, FIB USU, 2010.

Suprayitno, Mencoba Lagi Menjadi Indonesia: Studi Tentang Negara Sumatera Timur, 1947-1950, Yogjakarta, 2001.

Suprayitno, "The Struggle of T.M. Hasan in Government Building Republic of Indonesia in Sumatra (1945-1948)", Proceedding Seminar IAHA, Kedah, Malaysia 2014.

Suprayitno, "Melacak Hari Jadi Pemerintahan Kabupaten Karo 1945-1950", Makalah Seminar Hari Jadi Pemerintahan Kabupaten Karo, Berastagi, Agustus 2017.

Suprayitno, Biografi Pahlawan Nasional Djamin Gintings, Medan, 2016,

Surbakti, A.R., Perang Kemerdekaan di Karo Area, Medan: 1978.

Surbakti, A.R., Karo Area, Medan: Ulih Saber, 1995.

Tridah Bangun, Koran Karo-Karo Pejoeang 45 Multi Talenta, Medan: Tani Namura, 2002

Tridah Bangun, Hendri Khairuddin, Kilap Sumagan, Biografi Selamat Ginting, Jakarta: CV Haji Mas Agung, 1994.

Van de Velde, J.J., Surat-Surat dari Sumatera, Jakarta: Pustaka Azet, 1987.

Van Langenberg, Michael. "National Revolution in North Sumatra: Sumatera Timur and Tapanuli 1942-1950”, Disertasi Doktor, University of Sidney, 1976.

Himpoenan Oendang-Oendang Negara Republik Indonesia, "Penetapan Panitia 
Persiapan Kemerdekaan Indonesia Tentang Pembentoekan Komite Nasional di seloeroeh Indonesia, Gerakan Partai Nasional Indonesia, Badan Penoeloeng Korban Perang dan Badan Keamanan Rakjat', 1945.Koleksi SekNeg RI, ANRI. Koran Mestika, Selasa, 30 Oktober 1951.

Waspada, 1951.

Interview with H. Suwarta Sebayang, Perbesi, 18 Januari 2017.

Interview with Netapken S.Brahmana dan Mulih Hijrah S. Brahmana, (Anak Rakoetta S. Brahmana), Medan 17-1-2017.

Interview with Jenda Kita br. Sebayang, 98 Tahun (Teman sekolah adik Rakoetta Sembiring), Limang, 18 Januari 2017.

Interview with Sadah Arih br. Sinurat, 84 Tahun, Petani di Desa Limang, 18 -012017.

Interview with S. Tarigan, Veteran Pejuang Kemerdekaan RI, Berastagi, 25 -8- 2017. 